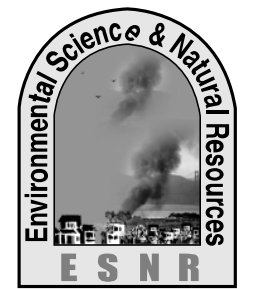

\title{
Phosphate Level in Some Selected Surface and Ground Water Bodies of Rajshahi City Corporation
}

\author{
M. A. Habib', M. A. Hoque ${ }^{2}$, M. S. Islam ${ }^{1}$, M. M. Islam ${ }^{1}$, and M. N. Islam ${ }^{1}$ * \\ ${ }^{1}$ Department of Chemistry, ${ }^{2}$ Department of Biochemistry and Molecular Biology, \\ University of Rajshahi, Rajshahi-6205 \\ *Corresponding author: mnurulchem@gmail.com
}

\begin{abstract}
Optimum $\mathrm{PO}_{4}-\mathrm{P}$ level in surface and ground water is essential for maintaining good health and environment. In this study, the $\mathrm{PO}_{4}-\mathrm{P}$ level was measured for 148 different water samples collected from ponds, supply tape and tube-well of 8 different areas of Rajshahi City Corporation. All the sites of surface water bodies crossed the United States Environmental Protection Agency (USEPA) criterion of 0.01-0.03 mg L $\mathrm{mO}_{4}-\mathrm{P}$ to be free from eutrophication. Among the samples, $4.2 \%$ were within the range $\left(0.025-0.1 \mathrm{mg} \mathrm{L}^{-1}\right)$ of onset of eutrophication while $95.8 \%$ crossed the hyper-eutrophication level $\left(>0.10 \mathrm{mg} \mathrm{L}^{-1}\right)$. However, most of the ground $(83.1 \%)$ and tap $(92.7 \%)$ water were excellent in quality for drinking with respect to $\mathrm{PO}_{4}-\mathrm{P}$ level $\left(<1 \mathrm{mg} \mathrm{L}^{-1}\right)$. Only $15.3 \%$ of ground water and $7.3 \%$ of tap water were good quality and a negligible amount $(1.6 \%)$ of ground water was fair quality.
\end{abstract}

Key words: Drinking water, Eutrophication, Ground water, Phosphate level, Surface water

\section{Introduction}

Phosphorus (P) is one of the essential macro nutrients for all living organisms as a component of biomolecules e.g. DNA, RNA, ATP etc. Like nitrogen, it is a limiting nutrient for algal growth, because it occurs in the least amount relative to the needs of plants (Chapman, 1992; Spraill et al., 1998; Murphy, 2005). Phosphorus occurs almost solely as dissolved phosphate in natural and waste water. The most thermodynamically stable form of phosphate is orthophosphate which is commonly identified in laboratory analysis and also used by plants. Polyphosphates in water are unstable and eventually convert to orthophosphate (Chapman, 1992; Spraill et al., 1998; Murphy, 2005; John De Zuane, 1990; Mueller et al., 1995; Nolan et al., 2000). Phosphates are moderately soluble in water and are not very mobile in soils. However, transportation through runoff and erosion can drastically enhance their levels in surface waters. Other factors that contribute to their low concentrations in water bodies include the usually large uptake by plants and adsorption by metal oxides (Mueller et al., 1995). Surface waters and ground water become contaminated from both natural and anthropogenic sources of phosphates. Natural sources of phosphorus in both surface and ground water include atmospheric deposition, natural decomposition of rocks and minerals, weathering of soluble inorganic materials, decaying biomass, runoff, and sedimentation. Anthropogenic sources include fertilizers, waste water and septic system effluent, animal wastes, detergents, industrial discharge, phosphate mining, drinking water treatment, forest fires, synthetic material development surface (Spraill et al., 1998; Murphy, 2005; Mueller et al., 1995; Nolan et al., 2000; Manahan, 1993). Extremely high levels of phosphates can cause digestive problems in human (Murphy, 2005). Furthermore, excessive amounts of phosphates in water bodies can lead to eutrophication, a condition of accelerated, algal production to extreme quantities until they die off. The bacteria responsible for their decomposition use up and hence deplete the dissolved oxygen concentration in the water bodies to such levels that can result in fish kills. Additionally excessive algae on the water surface can accumulate into a scum which can result in clogged pipelines, restricted recreation and foul odours, when they eventually decay (Spraill et al., 1998; Murphy, 2005; Mueller et al., 1995; Nolan et al., 2000; Banu et al., 2008). Also algal blooms have been linked to health problems such as skin irritation and death (of both human and animals) depending on the type and duration of exposure (Oram, 2005). $\quad \mathrm{PO}_{4}-\mathrm{P}$ level $>0.1 \mathrm{mgL}^{-1}$ may interfere with coagulation process in water treatment plants (Banu et al., 2008). As both high and low level of $\mathrm{P}$ is harmful for living organisms and environment, it is necessary to maintain the optimum $\mathrm{PO}_{4}-\mathrm{P}$ level in surface and ground water for maintaining good health and environment. Therefore, it is essential to know the $\mathrm{PO}_{4}-\mathrm{P}$ level of surface water and ground water bodies to take necessary measure for maintaining its optimum level. This paper aims at comparing experimental levels of total $\mathrm{PO}_{4}-\mathrm{P}$ in selected surface and ground water bodies in Rajshahi City Corporation area. It intends to predict the overall eutrophication risk and possible health hazards with respect to $\mathrm{PO}_{4}-\mathrm{P}$ level so that necessary control measures can be taken to avoid them.

\section{Materials and Methods}

\section{Instrumentation}

Micro-processor controlled UV-Visible spectrophotometer (UV-1800, SHIMADZU, Japan) was employed for the analysis of total $\mathrm{PO}_{4}-\mathrm{P}$ at the programmed reaction time and wavelength. 


\section{Reagents}

$\mathrm{NaOH}, \mathrm{HCl}, \mathrm{H}_{2} \mathrm{SO}_{4}, \mathrm{SnCl}_{2}$, ammonium molybdate, phenolphthalein indicator, glycerol and $\mathrm{Na}_{2} \mathrm{HPO}_{4}$ used in analysis were of analytical grade.

\section{Sample collection, pretreatment and storage}

Total of 148 water samples, 48 from ponds, 59 from tube-well and 41 from taps of different areas in Rajshahi City Corporation were collected. Samples were collected in $500 \mathrm{~mL}$ plastic bottles cleaned with $1: 1 \mathrm{HCl}$ aqueous solution and rinsed with distilled deionized water and were immediately analyzed (Fadiran et al., 2008). The collected samples were centrifuged to remove unwanted dust and particles and then were filtered to confirm clarification. For both surface and ground water series sampling was carried in September, 2013. In both cases the sites were so carefully chosen to ensure good representation of urbanization, agricultural and industrial activities, rock type of the area and other factors that influence the $\mathrm{PO}_{4}-\mathrm{P}$ levels.

\section{Principles}

Orthophosphate reacts with molybdate in an acidic medium to produce a phosphomolybdate complex. Stannous chloride $\left(\mathrm{SnCl}_{2}\right)$ then reduces the complex and develops an intense molybdenum blue colour (Ibanez et al., 2008).

\section{Analyses}

$0.5 \mathrm{ml}$ of sample was added to $10 \mathrm{~mL}$ deionized water. Then it was acidified with $0.01 \mathrm{M} \mathrm{HCl}$ using phenolphthalein as indicator. Ammonium molybdate reagent $(0.4 \mathrm{~mL})$ was added to the acidified sample and mixed well. Then 2 drops of $0.1 \mathrm{M} \mathrm{SnCl}_{2}$ solution in glycerol was added and was allowed to react for 10 minutes for colour development. The colour intensity was measured by the spectrophotometer at a wavelength of $690 \mathrm{~nm}$ (Ibanez et al., 2008). The $\mathrm{P}$ concentration was calculated using the standard calibration curve. To construct the calibration curve, a phosphate standard $\left(10 \mathrm{mg} \mathrm{L}^{-1} \mathrm{PO}_{4}-\mathrm{P}\right)$ was diluted serially within the expected real sample range. They were then analyzed following the same procedure as actual samples.

\section{Results and Discussion}

\section{$\mathrm{PO}_{4}-\mathrm{P}$ level in the water samples}

Tables 1 and 2 depict the $\mathrm{PO}_{4}-\mathrm{P}$ level in the sampled surface water and ground-water bodies with the observed prevalent features of the sites while Tables 3 and 4 show the risk level of categorization of the water bodies for eutrophication and health hazard with respect to their $\mathrm{PO}_{4}-\mathrm{P}$ level. The mean values of PO4-P in surface water, ground water and tap water in the different sampling are depicted in Figure 1.

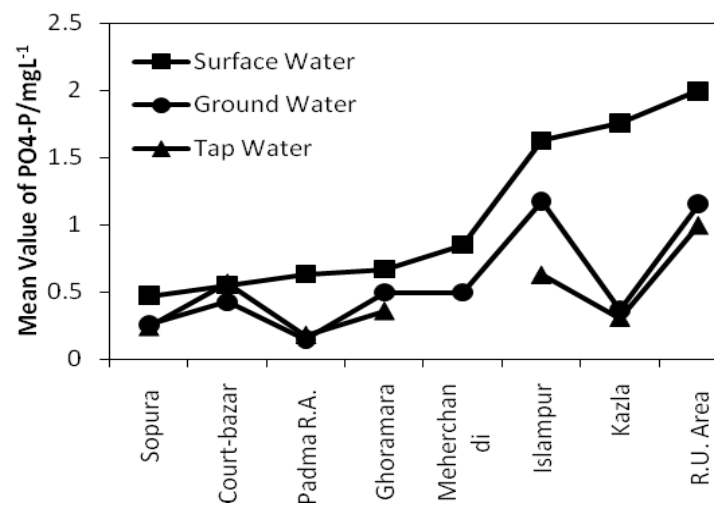

Fig. 1. The mean value of $\mathrm{PO}_{4}-\mathrm{P}$ in surface water, ground water and tap water in the different sampling area

It is apparent from Figure 1 that the mean $\mathrm{PO}_{4}-\mathrm{P}$ level in surface water is higher than ground water and tap water in all the sampling areas. However, the highest mean $\mathrm{PO}_{4}-\mathrm{P}$ level of surface water sample was found in Rajshahi University (RU) campus area $\left(2.0 \mathrm{mg} \mathrm{\textrm {L } ^ { - 1 }}\right)$. In this area the population density is very high. Most of the students and employees live in this area. Furthermore, many agricultural research work and cultivation are also done here. The second highest phosphate level was found Kazla area $\left(1.76 \mathrm{mg} \mathrm{L}^{-1}\right)$ followed by Islampur area $\left(1.63 \mathrm{mg} \mathrm{L}^{-1}\right)$ which are also densely populated. On the other hand, as expected the surface water has the lowest $\mathrm{PO}_{4}-\mathrm{P}$ level in Sopura $\left(0.47 \mathrm{mg} \mathrm{L}^{-1}\right)$ followed by Courtbazar $\left(0.55 \mathrm{mg} \mathrm{L}^{-1}\right)$ and Padma Residential Area (Padma R. A.) $\left(0.63 \mathrm{mg} \mathrm{L}^{-1}\right)$. Factors other than population density may be responsible in this case. Although the sub-urban area, Meherchandi has medium population density, the relative high $\mathrm{PO}_{4}-\mathrm{P}$ level $\left(0.85 \mathrm{mg} \mathrm{L}^{-1}\right)$ may be due to the runoff of phosphorus fertilizer from the agricultural lands around the surface water bodies.

The highest and the lowest mean $\mathrm{PO}_{4}-\mathrm{P}$ level of ground water were found in Islampur $\left(1.18 \mathrm{mg} \mathrm{L}^{-1}\right)$ and Padma R. A. $\left(0.15 \mathrm{mg} \mathrm{L}^{-1}\right)$. The second highest $\mathrm{PO}_{4}-\mathrm{P}$ level was found in $\mathrm{RU}$ area. The underground rock type is responsible for this variation. Almost same trend was observed in case of tap water samples. On average, the $\mathrm{PO}_{4}-\mathrm{P}$ level in tap water samples was lower than ground water samples. Precipitation of $\mathrm{PO}_{4}-\mathrm{P}$ in the water supply system may result in lower level in tap water. 
Table1. $\mathrm{PO}_{4}-\mathrm{P}$ level and dominant features of surface water (pond) sampling sites

\begin{tabular}{|c|c|c|c|c|c|c|}
\hline \multirow{2}{*}{$\begin{array}{l}\text { Sampling } \\
\text { area }\end{array}$} & \multirow{2}{*}{$\begin{array}{l}\mathrm{PO}_{4}-\mathrm{P} \text { range } \\
\left(\mathrm{mg} \mathrm{L}^{-1}\right)\end{array}$} & \multirow{2}{*}{$\begin{array}{c}\text { Population } \\
\text { of sampling } \\
\text { points }\end{array}$} & \multirow{2}{*}{$\begin{array}{c}\text { Mean value } \\
\text { of } \mathrm{PO}_{4}-\mathrm{P} \\
\left(\mathrm{mg} \mathrm{L}^{-1}\right)\end{array}$} & \multicolumn{3}{|c|}{ Dominant features } \\
\hline & & & & Location & $\begin{array}{l}\text { Population } \\
\text { density }\end{array}$ & Utilization \\
\hline Court-bazar & $0.35-0.76$ & 3 & 0.55 & Urban & High & $\begin{array}{l}\text { Fish farming, washing } \\
\text { and bathing }\end{array}$ \\
\hline Sopura & $0.18-0.68$ & 7 & 0.47 & Urban & High & $\begin{array}{l}\text { Fish farming, washing } \\
\text { and bathing }\end{array}$ \\
\hline Ghoramara & $0.05-1.46$ & 7 & 0.67 & Urban & High & Fish farming and bathing \\
\hline Meherchandi & $0.28-1.16$ & 7 & 0.85 & $\begin{array}{l}\text { Sub- } \\
\text { urban }\end{array}$ & Medium & $\begin{array}{l}\text { Fish farming, washing } \\
\text { and bathing }\end{array}$ \\
\hline Islampur & $0.40-2.57$ & 6 & 1.63 & Urban & High & $\begin{array}{l}\text { Fish farming, washing } \\
\text { and bathing }\end{array}$ \\
\hline Kazla & $1.31-2.04$ & 4 & 1.76 & Urban & High & $\begin{array}{l}\text { Fish farming, washing } \\
\text { and bathing }\end{array}$ \\
\hline Padma R.A. & $0.28-1.16$ & 7 & 0.63 & Urban & Medium & Washing and bathing \\
\hline RU Area & $0.55-6.20$ & 7 & 2.00 & $\begin{array}{l}\text { Sub- } \\
\text { urban }\end{array}$ & Medium & Fish farming and bathing \\
\hline
\end{tabular}

Table 2. $\mathrm{PO}_{4}-\mathrm{P}$ level and dominant features of ground and tap water sampling sites

\begin{tabular}{|c|c|c|c|c|c|c|}
\hline \multirow[t]{2}{*}{ Sampling Area } & \multicolumn{3}{|c|}{ Ground water (Tube-well) } & \multicolumn{3}{|c|}{ Tap water } \\
\hline & $\begin{array}{c}\mathrm{PO}_{4}-\mathrm{P} \text { range } \\
\left(\mathrm{mg} \mathrm{L}^{-1}\right)\end{array}$ & $\begin{array}{c}\text { Population } \\
\text { of sampling } \\
\text { points } \\
\end{array}$ & $\begin{array}{c}\text { Mean value of } \\
\mathrm{PO}_{4}-\mathrm{P} \\
\left(\mathrm{mg} \mathrm{L}^{-1}\right) \\
\end{array}$ & $\begin{array}{c}\mathrm{PO}_{4}-\mathrm{P} \text { range } \\
\left(\mathrm{mg} \mathrm{L}^{-1}\right)\end{array}$ & $\begin{array}{c}\text { Population } \\
\text { of sampling } \\
\text { points }\end{array}$ & $\begin{array}{c}\text { Mean value } \\
\text { of } \mathrm{PO}_{4}-\mathrm{P} \\
\left(\mathrm{mg} \mathrm{L}^{-1}\right) \\
\end{array}$ \\
\hline Court-bazar & $0.10-0.78$ & 3 & 0.43 & $0.48-0.65$ & 2 & 0.57 \\
\hline Sopura & $0.03-0.55$ & 7 & 0.26 & $0.05-0.38$ & 8 & 0.24 \\
\hline Ghoramara & $0.13-1.26$ & 9 & 0.50 & $0.20-0.71$ & 7 & 0.36 \\
\hline Meherchandi & $0.45-0.55$ & 2 & 0.50 & -- & -- & - \\
\hline Islampur & $0.23-1.79$ & 7 & 1.18 & $0.20-1.13$ & 7 & 0.63 \\
\hline Kazla & $0.25-0.45$ & 8 & 0.37 & $0.23-0.38$ & 5 & 0.31 \\
\hline Padma R.A. & $0.10-0.28$ & 9 & 0.15 & $0.08-0.28$ & 6 & 0.18 \\
\hline R.U. Area & $0.15-1.61$ & 14 & 1.16 & $0.25-2.09$ & 6 & 1.00 \\
\hline
\end{tabular}

\section{Eutrophication risk}

Table 3 shows the eutrophication risk level categorization of surface water bodies with respect to $\mathrm{PO}_{4}-\mathrm{P}$ level. All the sites of surface water bodies failed to meet the USEPA criterion of $0.01-0.03 \mathrm{mg}$ $\mathrm{L}^{-1} \mathrm{PO}_{4}-\mathrm{P}$ to be free from eutrophication (USEPA, 1986). Among the samples, $4.2 \%$ were within the range (0.025-0.1 $\left.\mathrm{mg} \mathrm{L}^{-1}\right)$ of onset of eutrophication while $95.8 \%$ crossed the hyper-eutrophication level (> $0.10 \mathrm{mg} \mathrm{L}^{-1}$ ) (Fig. 2). The house-hold effluents were the main sources of surface water in the sampling season. $\mathrm{PO}_{4}-\mathrm{P}$ level in the ground and tap water was also found to be high (Table 2).

Table 3. Risk level categorization of surface water bodies with respect to eutrophication

\begin{tabular}{|c|c|c|c|}
\hline $\mathrm{PO}_{4}$-Prange $\left(\mathrm{mg} \mathrm{L}^{-1}\right)$ & Class of risk & No. of samples & $\%$ of samples \\
\hline $0.01-0.03$ & Free from Eutrophication & 00 & 0.0 \\
\hline $0.025-0.1$ & Onset of Eutrophication & 02 & 4.2 \\
\hline$>0.10$ & Hyper- Eutrophication & 46 & 95.8 \\
\hline
\end{tabular}

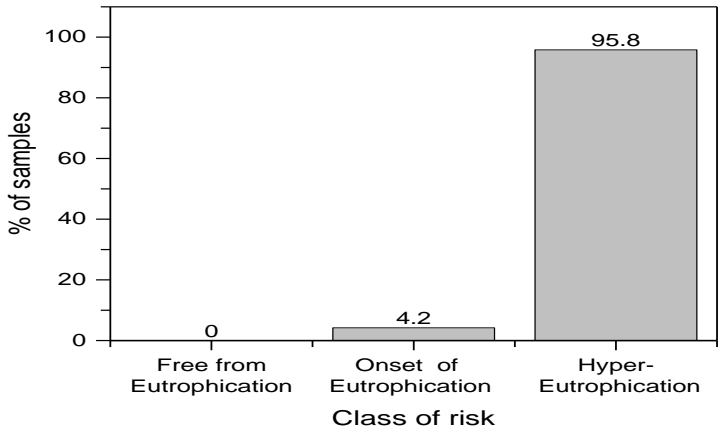

Fig. 2. Risk level categorization of surface water bodies for eutrophication with respect to $\mathrm{PO}_{4}-\mathrm{P}$ level
In addition to that a significant contribution to $\mathrm{PO}_{4}$ $P$ level comes from the detergent used for the laundry purposes. As a result, the $\mathrm{PO}_{4}-\mathrm{P}$ level in the surface water became higher and crossed the hyper eutrophication level in most of the cases. In such condition, algal production accelerated to extreme quantities until they die off. The bacteria responsible for their decomposition use up and hence deplete the dissolved oxygen concentration in the water bodies to such levels that can result in fish kills. Also algal blooms have been linked to health problems such as skin irritation and death (of both human and animals) depending on the type and duration of exposure (Oram, 2005). $\mathrm{PO}_{4}-\mathrm{P}$ level $>0.1 \mathrm{mg} \mathrm{L}^{-1}$ may interfere with coagulation process 
in water treatment plants (Banu et al., 2008). Thus extra care should be taken in the surface water bodies of this area for fish farming to avoid the adverse effect of eutrophication. Countries like the USA have banned the use of phosphate detergents with beneficial results (Guilbert et al., 1979). If government of Bangladesh can take a similar step, it would go a long way to enhance the quality of our water bodies with respect to their $\mathrm{PO}_{4}-\mathrm{P}$ levels.

\section{Drinking water quality}

People in the studied area mainly use ground and tap water as drinking water. We found that water of all those areas is safe for drinking or any other using in their daily life. Most of the ground (83.1\%) and tap $(92.7 \%)$ water were excellent in quality for drinking $\left(<1 \mathrm{mg} \mathrm{L}^{-1}\right)$ with respect to $\mathrm{PO}_{4}-\mathrm{P}$ level (Table 4) (John De Zuane, 1990). Only 15.3\% of ground water and $7.3 \%$ of tap water were good quality and a negligible amount $(1.6 \%)$ of ground water was fair quality (Fig. 3).

Table 4. Categorization of ground and tap water bodies as drinking water with respect to $\mathrm{PO}_{4}-\mathrm{P}$ level

\begin{tabular}{|c|c|c|c|c|c|c|}
\hline $\mathrm{PO}_{4}-\mathrm{P}_{\text {range }}$ & Drinking & \multicolumn{2}{|c|}{ Ground water } & \multicolumn{2}{c|}{ Tap water } \\
\cline { 3 - 6 } & water quality & No. of samples & \% of samples & No. of samples & $\%$ of samples \\
\hline$<1$ & Excellent & 49 & 83.1 & & 38 & 92.7 \\
\hline 1.1 to 4.0 & good & 09 & 15.3 & & 03 & 7.3 \\
\hline 4.1 to 9.9 & Fair & 01 & 1.6 & 00 & 0.0 \\
\hline
\end{tabular}

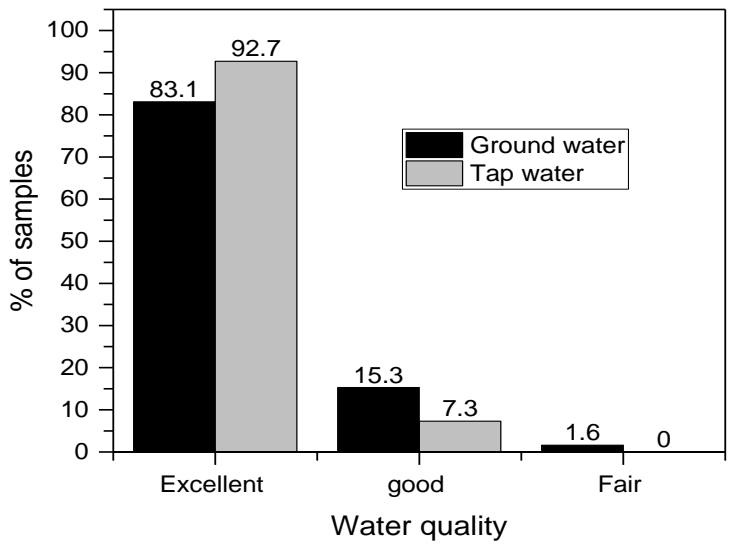

Fig. 3. Categorization of ground and tap water bodies as drinking water with respect to $\mathrm{PO}_{4}-\mathrm{P}$ level

\section{Conclusions}

This paper describes the levels of total $\mathrm{PO}_{4}-\mathrm{P}$ in selected surface and ground water bodies in Rajshahi City Corporation area. Almost $100 \%$ of the analyzed surface water and ground water samples exceed the maximum acceptable level of $0.10 \mathrm{mg} / \mathrm{L} \mathrm{PO}_{4}-\mathrm{P}$ for prevention of eutrophication. It follows that virtually all the water bodies are

\section{References}

Banu, R. J.; Do, K. U. and Yeom, I. T. 2008. Phosphorus Removal in Low Alkalinity Secondary Effluent Using Alum. Int. J. Environ. Sci. Tech., 5 (1): 93-98.

Chapman, D. 1992. Water Quality AssessmentsA Guide to the Use of Biota, Sediments and Water in Environmental Monitoring. Chapman and Hall, London, UK. pp.76-78.

Fadiran, A. O.; Dlamini, S. C. and Mavuso, A. 2008. A comparative study of the phosphate levels in some surface and ground water bodies of Swaziland. Bull. Chem. Soc. Ethiop, 22(2): 197-206. already under hyper-eutrophic state. Hence to forestall an outbreak of an uncontrollable hypereutrophic state in Rajshahi City Corporation area water bodies, steps have to be taken early enough to control the ascribes of phosphorus from anthropogenic sources into these water bodies. Furthermore, it has become necessary to include phosphorus in basic water quality surveys or background monitoring programmes. Treatment of waste water as well as effluent discharges from industry and factories into receiving waters and the environment of the country should be properly controlled and monitored. Our results confirm that surface water have the tenancy to have higher phosphate concentrations than ground waters as well as tap water.

\section{Acknowledgments}

The authors are grateful to the Department of Chemistry, University of Rajshahi, Bangladesh for providing financial support and laboratory facilities to carry out this research work.

Guilbert, P. A. and Dejoy, A. L. 1979. Phosphorus in the Environment: Its Chemistry and Biochemistry. The Use of Phosphate Detergents and Possible Replacements for Phosphate. CIBA Foundation Symposium 57. Amsterdam, Netherlands.

Ibanez, J. G.; Hemandez-Esparza, M.; DoriaSerrano, C.; Fregoso-Infante, A. and Singh, M.M. 2008. Environmental Chemistry: Microscale Laboratory Experiments. Springer Science+ Business Media, LLC, New York, USA. 
John, D. and Zuane, P. E. 1990. Handbook of Drinking Water Quality-Standards and Controls, Van Nostrand Reinhold. New York, USA. pp.132-134.

Manahan, S. E. 1993. Fundamentals of Environmental Chemistry, Lewis Publishers, London, UK. p.504.

Mueller, D. K.; Hamilton, P. A.; Helsel, D. R.; Hitt, K. J. and Ruddy, B. C. 1995. US Geological Survey Water Resources Investigations Report 95-4031, Denver, Colorado.

Murphy, S. 2005. USGS Water Quality Monitoring, available at http://www.water.usgs.gov/nawqa/ circ-1136.

Nolan, B. T. and Stoner, J. D. 2000. Nutrients in ground waters of the conterminous United States 1992-1995. Environ. Sci. Technol., 34:1156-1165.
Oram, B. 2005. Wilkes University Center for Environmental Quality, GeoEnvironmental Sciences and Engineering Department, Phosphate and Water Quality. Available @ http://www.water.research.net/watershed, A.O.

Spraill, T. B.; Harned, D. A.; Ruhl, P. M.; Eimers, J. L.; McMahon, G.; Smith, K. F.; Galeone, D. R. and Woodside, M. D. 1998. U.S. Geological Survey Circular 1157; online at URL: http://water.usgs.gov/pubs/circ.1157.

USEPA. 1986. Quality Criteria for Water. U. S. Environmental Protection Agency Report, EPA. 440/5-86-001. 